\title{
WAKAF PRODUKTIF DAN PROBLEMATIKANYA DI DUNIA PESANTREN
}

\author{
Achmad Siddiq \\ STIT Raden Wijaya Mojokerto \\ Email: Siddiq_s308@yahoo.com
}

\section{Abstract}

Productive waqf is a new paradigm introduced in several regulations of endowment in Indonesia. This paradigm requires the management of waqf assets to be more productive, including "pesantren" as an institution that possesses numerous areas of waqf. This situation leads to various problems at pesantren institutions to implement the paradigm of productive waqf. The problems are related to the problems of public ownership to waqf asset, asset status, and legal persons of waqf especially in the sense of the competence and professionalism of nazhir at pesantren.

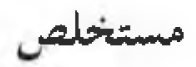

تعتبر الأوقاف المنتجة هي النموذج الجديد الذي أوردته ثنظيمة الوقنية في إندونيسيا. هذا

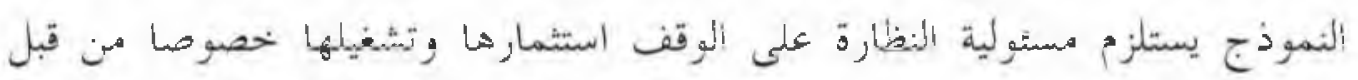

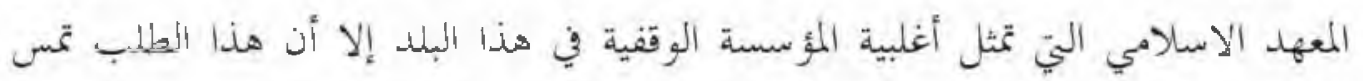

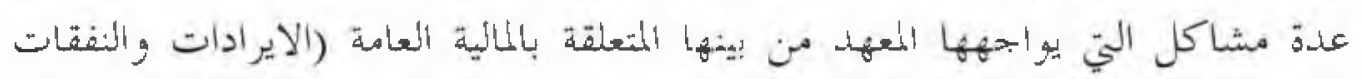
العامة) وأوضاعها الثقانونية إضافة إلى كفاءة الثناظر ومهنته.

Keywords: Wakaf, Produktif, Pesantren

\section{A. Pendahuluan}

Wakaf merupakan salah satu pilar filantropi yang dikenal dalam Islam. Secara historis, perjalanan wakaf nampak statis dibandingkan dengan pengelolaan dana sosial lain seperti zakat, infaq dan sedekah sehingga dapat dikatakan bahwa pengelolaan wakaf di Indonesia masih jauh dari harapan. Hal ini dapat dimaklumi 
sebagai konsekuensi kenyataan sejarah yang menunjukkan adanya kondisi di mana tradisi pemanfaatan wakaf sangat berkaitan langsung dengan corak penyebaran dan perkembangan Islam di Nusantara.

Kenyataan di atas tidak mengherankan manakala wakaf untuk masjid, lembaga pendidikan seperti pesantren dan kuburan merupakan jenis wakaf yang paling dikenal di dalam masyarakat, bahkan sejak abad $12 \mathrm{M}$ bersamaan Islam menjadi kekuatan sosial politik dengan kemunculan berbagai kerajaan Islam di nusantara. Dinamika demikian sekaligus memberikan corak wakaf di Indonesia yang identik dengan corak keagamaan karena bentuk wakaf yang didominasi dalam bentuk masjid, pesantren sehingga jarang ditemukan wakaf untuk tujuan-tujuan produktif atau aspek kehidupan sosial ekonomi lain. ${ }^{1}$

Sebetulnya, wakaf di Indonesia memiliki potensi yang cukup besar dan dapat menjadi sumber dana alternatif bagi pembangunan nasional. Data Kementerian Agama menyebutkan bahwa luas tanah wakaf sampai akhir tahun 2002 adalah 1,5 milyar meter persegi yang tersebar di 359.462 lokasi dan mayoritas dari potensi itu adalah wakaf berupa masjid atau mushalla, pesantren dan pekuburan. ${ }^{2}$ Potensi wakaf tersebut belum terkelola secara optimal sehingga kontribusinya dalam bidang sosial ekonomi untuk peningkatan kesejahteraan umat dirasa kurang, tidak demikian di bidang keagamaan. Kenyataan demikian tak mengherankan karena regulasi perwakafan di Indonesia dalam sejarahnya berjalan lambat dan kurang menguntungkan bagi pengembangan wakaf sehingga dinamika perwakafan di Indonesia terlihat statis dan pengelolaannya cenderung konsumtif.

Perwakafan di Indonesia mulai mendapatkan perhatian yang lebih dari masyarakat maupun pemerintah sejak penerbitan regulasi wakaf yang mandiri yakni penerbitan Undang Undang Nomor 41 Tahun 2004 tentang Wakaf. Undang-undang tersebut mengamanatkan agar wakaf dikelola secara produktif dan tidak konsumtif, sehingga wakaf dapat memberikan kontribusi bagi penanggulangan persoalan ekonomi umat. ${ }^{3}$ Paradigma wakaf produktif ini menjadi tuntutan bagi institusi wakaf khususnya pesantren. Hal ini disebabkan karena pesantren merupakan bagian dari institusi wakaf mayoritas di Indonesia, di samping pesantren juga mempunyai

1 Tuti A. Najib dan Ridwan al-Makassary, Wakaf, Tuhan dan Agenda Kemanusiaan, (Jakarta: CSRC UIN Jakarta, 2006), hal. 72-76 dan 121.

2 Dirjen Bimas Islam dan Penyelenggaraan Haji, Pedoman Pengelolaan dan Pengembangan Wakaf, (Jakarta: Dirjen BIPH, 2003).

3 Yusuf Suyono, Wakaf Produktif di Indonesia: Studi atas Pengelolaan Aset Wakaf Pondok Modern Gontor Ponorogo,(Semarang: IAIN Walisongo, 2007), hal. 2-3. 
kedudukan yang relatif kuat di mata masyarakat bahkan mampu mengalahkan kultur masyarakat itu sendiri. Pesantren mampu bertahan selama berabad-abad dalam menerapkan nilai-nilai hidupnya sendiri dan mampu melakukan transformasi total dalam sikap hidup masyarakat sekitarnya tanpa mengorbankan identitas dirinya. $^{4}$

Kedudukan pesantren yang demikian diharapkan agar pesantren mampu menjadi pioner dan garda depan bagi pengelolaan wakaf secara produktif di Indonesia sehingga pesantren tidak hanya melaksanakan fungsi-fungsi tradisionalnya seperti transformasi ilmu, pemeliharaan tradisi dan reproduksi ulama, namun juga dapat berfungsi sebagai agen perubahan dan pembangunan kemasyarakatan serta pusat pemberdayaan ekonomi. ${ }^{5}$

Potensi yang besar sekaligus praktik wakaf pesantren yang telah lama terpola pada paradigma pengelolaan yang cenderung konsumtif, tentu akan menimbulkan berbagai problematika tersendiri ketika pesantren tersebut harus merespon paradigma wakaf produktif yang baru. Problematika tersebut hendak dideskripsikan dalam tulisan ini, namun sebelumnya tulisan ini akan diawali dengan uraian makna atau konsep wakaf yang esensi sebagai institusi filantropi Islam yang harus dikelola dan dikembangkan secara produktif, kemudian dijelaskan juga respon yang selama ini telah dilakukan pesantren dalam pengelolaan wakaf pesantren dengan paradigma produktif.

\section{B. Paradigma Produktif dalam Konsep Wakaf}

Wakaf adalah salah satu icon filantropi yang telah dikenal dan dipraktikkan sejak lama dalam sejarah umat manusia. Pada masa pra Islam, wakaf telah dipraktikkan oleh masyarakat khususnya pada hal-hal yang menyangkut tempat peribadatan. ${ }^{6}$ Kemudian pada masa Islam, wakaf berkembang tidak hanya terbatas pada tempat peribadatan namun juga menyangkut segala harta benda yang dapat diproduktifkan seperti wakaf atas budak, hutang dengan akad qardhun hasan dan sebagainya. ${ }^{7}$ Sejarah mencatat bahwa awal wakaf dalam Islam dicontohkan oleh

4 Abdurrahman Wahid, "Pesantren sebagai Subkultur" dalam M. Dawam Rahardjo (ed), Pesantren dan Pembaharuan, (Jakarta: LP3ES, 1974), hal. 43.

5 Baca tulisan Azyumardi Azra, "Pesantren: Kontinuitas dan Perubahan" dalam Nurchlis Madjid. Bilik-bilik Pesantren: Sebuah Potret Perjalanan, (Jakarta: Paramadina.1997).

6 Muhammad Abû Zahrah. Muhadlarât fi al-Waqf. (Kairo: Dır al-Fikr al-'Araby, 2004), hal 9.

7 Ibid. 
nabi pada pendirian Masjid Quba' yang dibangun di atas tanah milik anak yatim Bani Najjır yang mana nabi membelinya seharga seratus dirham lalu mewakafkannya. Di samping itu, nabi juga mewakafkan tujuh kebun kurma milik Mukhairiq. ${ }^{8}$

Apa yang dilakukan nabi ini kemudian diikuti sahabat. Sebut saja Utsmân bin affân yang telah membeli sumur (bi'ru) rûmah dan mewakafkannya untuk kepentingan kaum muslimin, Abû Tholhah yang telah mewakafkan kebun kurma "bayruhâa” miliknya, 'Umar bin al-Khattıb yang mewakafkan tanah khaibar miliknya.9 Begitu juga 'Alî bin Abî Thâlib telah mewakafkan tanah "yanbû"” untuk kaum fakir miskin dan kepentingan publik lainnya. Bahkan hingga di penghujung pemerintahan Umar bin al-Khattılb, sahabat Jabir bin 'Abdillâh telah menyaksikan bahwa ketiadaan satupun sahabat yang berharta kecuali mereka mewakafkan hartanya sebagai sadaqah yang abadi yakni wakaf. ${ }^{10}$

Meski secara sosio historis di atas, wakaf telah menjadi praktik publik, namun secara yuridis formal, legalitas wakaf didasarkan atas tiga dasar utama: ${ }^{11}$ Pertama, hadits riwayat Abû Hurairah yang menyatakan bahwa nabi bersabda "Idzâ mâta ibnu âdam inqatha'a 'amaluhu illâ min tsalatsin shadaqatin jâriyah wa 'ilmin yuntafa'u bihi wa waladin shâlihin yad'û lahu”. Ibn Abbas dan beberapa sahabat lainnya seperti Mu'âdz bin Jabal, Zayd bin Tsâbit, Â'isyah, Khâlid bin al-Walîd, Jâbir bin 'Abdillâh dan sebagainya memandang bahwa yang dimaksud kata "shadaqatin jâriyah" dalam teks hadits tersebut adalah wakaf karena harta pokoknya tertahan namun hasilnya tetap mengalir. ${ }^{12}$ Kedua, hadits yang populer dan bahkan menjadi rujukan utama sebagai dasar legalitas wakaf yakni hadits riwayat Ibn 'Umar. Dalam hadits tersebut dijelaskan bahwa 'Umar pernah meminta petunjuk kepada

8 Mundzir Qahaf. Al-Waqf al-Islâmî, Tathawwuruhu, Idârâtuhu, Tanmiyatuhu. (Damaskus: Dâr al-Fikr, 2006), hal. 19-20. Mukhairiq adalah seorang Yahudi sekaligus pengagum nabi. ia ikut perang dalam barisan kaum muslimin di dalam perang uhud, dan ia berwasiat jika dirinya gugur di dalam perang tersebut maka hartanya berupa tujuh buah lahan korma tersebut diserahkan otoritas peruntukannya kepada nabi Muhammad, dan ternyata ia gugur sehingga nabi mengambil kebijakan untuk mewakafkannya. Kisah ini dapat dibaca juga di dalam kitab karya Abî Muhammad 'Abd alMalik Ibn Hisyâm. As-Sîrah al-Nabawiyyah. (Beirut: Dâr al-Kutub al-'Ilmiyyah, 2007), hal. 208.

9 Mundzir Qahaf, Al-Waqf al-Islâmî..., hal. 20-22.

${ }_{10} \mathrm{Mu}$ à pafâ Ahmad az-Zarqâ, Ahkâm al-Auqâf, (t.tp: Dâr 'Ammâr, tt), hal. 12; Lihat juga Ibrâhim Mahnûd 'Abd al-Bâqî. Dawr al-Waqf fî Tanmiyat al-Mujtama' al-Madanî. (Kuwait: alAmânah al-'Âmmah li al-Awqâf, 2006), hal. 42.

11 Muhammad Abû Zahrah. Munhadlarât ..., hal. 11.

12 az-Zarqâ. Ahkâm...,hal. 13. al-Nawawi menyebut hadits ini sebagai dasar legalitas wakaf al-

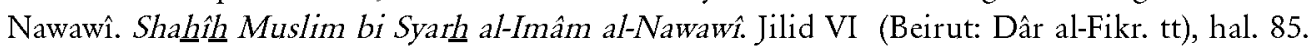


Nabi tentang pemanfaatan tanah miliknya bernama "tsamgha" yang berada di Khaibar, ${ }^{13}$ Nabi kemudian berkata "...in syi'ta habbbasta ashlahâ wa tashaddaqta bihâ... ${ }^{14}$ (jika kamu berkehendak, tahanlah pokoknya dan sedekahkanlah hasil atau manfaatnya). Atas saran nabi inilah kemudian 'Umar menyedekahkan tanah khaibar tersebut kepada kaum fakir, kerabat, hamba, kepentingan umum (sabîlillâh), tamu dan ibnu sabîl dengan sebuah komitmen ia tidak akan menjual, menghibahkan dan mewariskan tanah tersebut, ia juga berpesan agar pemelihara atau nazhir atas tanah tersebut dapat mengambil hasilnya asalkan secara baik dan bijaksana (bi alma'rûff). ${ }^{15}$ Ketiga adalah praktik (atsar) wakaf para sahabat nabi sebagaimana dijelaskan di atas.

Dasar sosio historis dan yuridis di atas mengokohkan wakaf sebagai salah satu lembaga filantropi Islam yang mempunyai karakter adanya perlindungan dan pelestarian harta benda yang diwakafkan oleh seseorang serta penyaluran hasil atau manfaat dari harta benda tersebut secara terus menerus. Karakter demikian menunjukkan bahwa wakaf menghendaki adanya suatu aktifitas pengelolaan harta secara produktif sehingga hasil atau manfaat yang diberikan oleh harta benda tersebut dapat berlangsung lama, dan oleh karena itu wakaf juga dikenal dengan sebutan a adaqah jâriyah. Karakter wakaf yang demikian sekaligus menegaskan bahwa esensi wakaf adalah produktif yakni suatu usaha yang mengupayakan benda wakaf dapat mendatangkan hasil atau manfaat. ${ }^{16} \mathrm{Hal}$ ini tentu berbeda dengan jenis filantropi lainnya seperti hibah, zakat, infaq dan sadaqah yang harus habis dibagi dan segera dimanfaatkan tanpa ada kewajiban mustahiqqîn (orang yang berhak menerima) untuk melestarikannya. Dengan kata lain dapat dikatakan bahwa pada dasarnya harta diciptakan untuk diambil manfaatnya yang mana pemanfaatannya dapat dilakukan dengan dua cara, yakni cara menghabiskan harta benda tersebut seperti

13 Lihat Muhammad Mua tafâ Syalabî, Muha hadarât al-Waqf wa al-Wa $a^{\underline{a}}$ iyyah al-Iskandariyyah: Mapba'ah Dâr at-Ta'lîf, 1957), hal. 23.

14 Pernyataan nabi ini dapat terlihat di masing-masing kitab (shahîh ataupun sunan) para imam (al-aimmah) al-sittah dengan redaksi yang sama. Hanya saja al-Nasâi dan Ibnu Mâjah juga menambahkan riwayat hadits lain dengan redaksi "...ihbis ashlahâ wa sabbil tsamratahâ" yang menurut al-Suyûthi maksudnya adalah jadikanlah hasil atau manfaat dari benda wakaf tersebut untuk sabilillah atau kepentingan umum. Lihat Jalâl al-Dîn al-Suyûthî. Sunan al-Nasâî bi Syarh Jalâl al-Dîn al-Suyûthî. (Beirut: Dâr al-Fikr.1930), hal. 232.

15 Abî 'Abdillâh Muhammad bin 'Ismâ'îl al-Bukhârî, Matn al-Bukhârî bi Hâasyiat al-Sanadî Juz III. (Beirut: Dâr al-Fikr, tt), hal. 196.

16 Ahmad Muhammad 'Abd al-Ażim Jamal., Daur Niżâm al-Waqf al-Islâmî fi at-Tanmiyyah al-Iqti âadiyyah al-Mu'ầitirah, (Kairo: Dâr as-Salâm, 2007), hal. 126. 
pada hibah, zakat dan sadaqah, atau dengan cara menggunakan harta secara terus menerus dengan tetap menjaga kelanggengan benda tersebut yakni wakaf. ${ }^{17}$

Paradigma wakaf produktif telah lama dilakukan dan nampak berkembang di berbagai kawasan dunia Islam. Di Turki, sejak masa Daulah Abbasiyyah dan Kekaisaran Turki Usmani, wakaf merupakan unit filantropi yang dapat dimanfaatkan pada sektor pendidikan dan penelitian, sektor seni dan budaya, dan wakaf tunai telah dikenal dan dipraktikkan pada masa itu. Adapun sekarang wakaf di negara tersebut sudah terkelola secara profesional dan bahkan dalam wujud investasi di berbagai ladang bisnis. ${ }^{18}$ Di Iran, wakaf sudah merambah pada pembiayaan sektor infra struktur, wisata, dan layanan kesehatan sejak abad ke-10 masehi, begitu juga di Mesir dengan wakaf al-Azhar-nya, Kuwait dengan peran Kuwait Awqaf Publik Foundation (KAPF) yang telah mengantarkan wakaf di negara tersebut menjadi institusi yang mandiri dan mampu menopang kehidupan sosial ekonomi negara. ${ }^{19}$

\section{Paradigma Wakaf Produktif dan Respon Pesantren terhadapnya: Antara Keniscayaan dan Kenyataan}

Perbincangan wakaf di Indonesia tidak dapat dipisahkan dengan regulasi perwakafan yang mengaturnya. Wacana wakaf produktif mulai bergulir dan mendapatkan perhatian sejak kehadiran Undang-Undang Nomor 41 Tahun 2004 tentang Wakaf beserta peraturan pelaksanaannya yaitu Peraturan Pemerintah Nomor 42 Tahun 2006 tentang Pelaksanaan Undang-Undang Nomor 41 Tahun 2004 tentang Wakaf. Banyak hal baru yang diatur oleh peraturan perundang-undangan ini dibanding regulasi sebelumnya, salah satu yang esensial adalah paradigma pengelolaan dan pengembangan harta benda wakaf yang ditahbiskan dengan semboyan paradigma produktif. ${ }^{20}$

Paradigma wakaf produktif tersebut muncul sebagai respon atas realitas perwakafan nasional yang cenderung konsumtif sebagai dampak atas obyek wakaf yang didominasi dan terbatas dalam wujud tanah sehingga tak heran jika regulasi wakaf tidak independen ketika itu, namun digantungkan atau dijadikan sisipan

17 Mushtafâ Ahmad az-Zarqâ, Ahkâm al-Awqâf...., hal. 9.

18 Tuti A Najib dan Ridwan al-Makassary (ed), Wakaf..., hal. 49-50.

19 Ibid.

20 Paradigma ini nampak dalam pernyataan pasal 43 ayat 2 Undang-Undang Nomor 41 Tahun 2004 tentang Wakaf yang berbunyi, "pengelolaan dan pengembangan harta benda wakaf sebagaimana dimaksud ayat (1) dilakukan secara produktif. 
pada regulasi pertanahan yakni Undang-Undang Pokok Agraria Nomor 5 Tahun 1960 tentang ketentuan pokok Agraria, kemudian diperjelas dengan Peraturan Menteri Agama Nomor 1 tahun 1978 tentang Peraturan Pelaksanaan Peraturan Pemerintah Nomor 28 tahun 1977 tentang Perwakafan Tanah Milik. ${ }^{21}$

Eksistensi wacana produktif di atas merupakan semangat baru yang hendak menjadikan wakaf sebagai instrumen untuk menyejahterakan masyarakat muslim dengan cara menjadikan pengelolaan wakaf yang semula lebih konsumtif kearah pengelolaan yang produktif, oleh karena itu pendekatan yang digunakan tidak hanya pendekatan ekonomi semata namun juga harus digunakan pendekatan bisnis. ${ }^{22}$ Semangat ini nampak pada upaya regulasi wakaf yang mewajibkan nazhir untuk mengelola dan mengembangkan harta benda wakaf sesuai dengan tujuan, fungsi dan peruntukannya dan harus dilakukan secara produktif tanpa melanggar prinsipprinsip syari'ah. Pengelolaan dan dan pengembangan secara produktif tersebut antara lain dengan cara pengumpulan (fundraising), investasi, penanaman modal, produksi, kemitraan, perdagangan, agrobisnis, pertambangan, perindustrian, pengembangan teknologi dan pembangunan gedung, apartemen, rusun, pasar swalayan, pertokoan, perkantoran, sarana pendidikan dan usaha-usaha yang tidak bertentangan dengan syari'ah. pengelolaan dan pengembangan wakaf semacam ini diharapkan dapat dikelola oleh nazhir dengan pendekatan bisnis yakni usaha yang berorientasi pada keuntungan dimana keuntungan tersebut dapat disedekahkan kepada para pihak yang berhak menerimanya. ${ }^{23}$

Wacana wakaf produktif yang telah dikuatkan dengan regulasi di atas tentu menjadi tantangan bagi institusi wakaf selama ini yang dominan dalam bidang keagamaan dan dalam wujud obyek tanah dan bangunan serta cenderung konsumtif, tak terkecuali institusi pondok pesantren yang mayoritas asetnya dalam bentuk tanah dan bangunan sebagai warisan tradisi masa lalu. Kini, dengan konsep wakaf produktif, pesantren dituntut untuk mengelola manajemen institusinya yang mayoritas berstatus wakaf agar bergerak dinamis hingga terwujud sebagai institusi wakaf pesantren yang produktif dan institusi dakwah yang tidak terbatas di bidang keagamaan dan pendidikan semata, akan tetapi mampu menjadi institusi yang dapat memberikan kontribusi sosial ekonomi masyarakat melalui program

21 Rahmadi Usman, Hukum Perwakafan di Indonesia, (Jakarta: Sinar Grafika, 2009), hal. 2-7).

22 Jaih Mubarok, Wakaf Produktif, (Bandung: Simbiosa Rekatama Media, 2008), hal. 27.

23 Ibid, hal. 28. Lihat juga bunyi Pasal 42 dan 43 Undang Undang Nomor 41 Tahun 2004 tentang Wakaf. 
pengembangan masyarakat, peningkatan partisipasi publik, dan advokasi kebijakan yang memihak pada masyarakat lemah. ${ }^{24}$ Keniscayaan ini perlu direalisasikan mengingat mayoritas wakaf sejak awal pertumbuhannya tersedot untuk membiayai fasilitas keagamaan dan pendidikan sebagaimana terdapat dalam institusi pesantren. ${ }^{25}$

Secara umum, institusi pesantren yang telah merespon wacana wakaf produktif ini dapat dikata masih minim. Meskipun demikian, beberapa pesantren yang ada di Indonesia telah menunjukkan respon atas wacana wakaf produktif tersebut dengan berupaya mengelola aset wakafnya ke arah paradigma produktif. Pesantren Modern Darussalam Gontor misalnya, ${ }^{26}$ telah mengembangkan pengelolaan aset wakaf pesantren dengan menginvestasikan aset wakaf yang dikelolanya dalam bentuk unitunit usaha berbasis manajemen modern, mengadakan perluasan bentuk wakaf yang tidak hanya terbatas pada benda tetap tapi juga benda bergerak, adanya penukaran benda wakaf yang selama ini diperspektifkan sebagian besar pelaku wakaf sebagai something closed dan tak kalah pentingnya pesantren ini menerapkan pemanfaatan hasil wakaf yang tidak terbatas pada aspek ibadah an sich, namun menembus pada peningkatan ekonomi dan kesejahteraan umat. ${ }^{27}$ Tak heran manakala aset wakaf pesantren ini mengalami dinamika yang cukup fantastis, jika pada saat diwakafnya pada tahun 1958 pesantren Gontor memiliki aset tanah sebanyak 18,59 hektar, maka pada tahun 2009 aset tanah pesantren ini berkembang menjadi 825,184 hektar, yang kurang lebih 651 hektar diantaranya merupakan tanah wakaf. Aset tanah tersebut diperoleh melalui wakaf, hibah, tukar menukar, dan pembelian. Di samping itu, pesantren ini telah menginvestasikan aset wakafnya dalam 27 unit usaha produktif. ${ }^{28}$

Selain Pesantren Modern Darussalam Gontor, Pesantren Tebuireng juga mulai nampak bergerak ke arah pendayagunaan aset wakaf secara produktif meskipun

24 Tuti A. Najib dan Ridwan Al-Makassary, Wakaf..., hal. 23.

25 Muhammad Fuad, Membangun Raksasa Tidur, Problematika Pengelolaan dan Pendayagunaan Wakaf di Indonesia, (Piramedia: Depok, 2008), hal. 76.

26 Irfan Abubakar, "Pengelolaan Wakaf di Pondok Modern Gontor Ponorogo: Menjaga Kemandirian Civil Society" dalam Chaider S Bamualim dan Irfan Abubakar (ed), Revitalisasi Filantropi Islam, (Jakarta: PBB UIN Jakarta, 2005), hal. 226-233, 245-247. Baik Yusuf Suyono dkk maupun Irfan Abu Bakar dalam penelitiannya tentang Pesantren Modern Darussalam Gontor (PMDG) menyimpulkan bahwa pesantren ini telah menjalankan paradigma wakaf produktif sebagaimana terkonstitusionalkan dalam regulasi perwakafan Indonesia.

27 Yusuf Suyono dkk, Wakaf Produktif..., hal. 154-156.

28 Abdullah Syukri Zarkasyi, Manajemen Pesantren: Pengalaman Pondok Modern Gontor, (Ponorogo: Trimurti Press, 2005), hal. 186. 
proses institusionalisasi wakaf pesantren ini tergolong terlambat. Hal ini diindikasikan dari adanya pengelolaan aset-aset produktif seperti sawah dan kebun yang hasilnya didistribusikan pada kemakmuran pesantren khususnya pembiayaan pendidikan di dalamnya. ${ }^{29}$ Meski manajemen wakaf di pesantren ini belum sampai pada taraf profesional namun pesantren ini memiliki kekuatan dalam strategi penggalangan dana (fundrising) dan pengembangan wakaf sebagaimana terlihat dari kemajuan dalam penyediaan fasilitas pendidikan di dalamnya. ${ }^{30}$

Pesantren lain yang dapat dijadikan contoh pengelolaan aset wakaf produktif adalah pesantren Asshiddiqiyah. Pesantren ini mampu menaikkan aset wakaf dari tanah wakaf seluas $2.600 \mathrm{~m}^{2}$ dengan sebuah mushollah menjadi pesantren besar dengan aset tanah seluas sekitar 15 hektar, ${ }^{31}$ di samping itu pesantren ini mengembangkan berbagai usaha baik berupa sawah maupun usaha bisnis yang hasilnya diorientasikan pada pembiayaan operasional dan penambahan fasilitas pesantren serta membantu ekonomi masyarakat sekitar khususnya orang tua santri. ${ }^{32}$

Tiga pesantren di atas adalah beberapa contoh pesantren yang terlihat responsif dengan urgensi pengelolaan dan pengembangan aset wakaf secara produktif. Meski tidak terlalu ideal untuk dikatakan sebagai institusi wakaf yang profesional, namun setidaknya beberapa pesantren tersebut telah memberikan inspirasi bagi pesantren lain untuk menjadikan institusi wakaf pesantren sebagai institusi wakaf yang produktif dan tidak hanya berorientasi pada aspek pure keagamaan semata namun dapat memberikan nilai plus dalam peningkatan kesejahteraan umat.

\section{Problematika Implementasi Wakaf Produktif di Dunia Pesantren}

Secara umum, wakaf di Indonesia belum berperan dalam memberdayakan ekonomi umat. Uswatun Hasanah mengemukakan beberapa faktor penyebabnya antara lain: Pertama, masalah pemahaman masyarakat tentang hukum wakaf. Pada umumnya masyarakat belum memahami hukum wakaf dengan baik dan benar, baik dari segi rukun dan syarat wakaf, maupun maksud disyari’atkan wakaf. Kedua,

29 Irfan Abubakar, "Pelembagaan Wakaf di Pesantren Tebuireng Jombang: Sebuah Upaya Merespon Kebutuan akan Perubahan" dalam Chaider S Bamualim dan Irfan Abubakar (ed), Revitalisasi Filantropi Islam, (Jakarta: PBB UIN Jakarta, 2005), hal. 283-295.

${ }^{30}$ Ibid. juga lihat tulisan Miftahul Huda, Fundrising Wakaf dan Kemandirian Pesantren (Strategi Nazhir Wakaf Pesantren dalam Menggalang Sumber Daya Wakaf, Makalah The $9^{\text {th }}$ Annual Conference on Islamic Studies (ACIS) di Solo tahun 2009, tidak dipublikasikan.

31 Muhammad Fuad, Membangun..., hal. 95.

32 Ibid, hal. 75. 
pengelolaan dan manajemen wakaf yang tidak professional. Ketiga, obyek wakaf yang cenderung berupa aset statis yang sulit dikembangkan. Keempat adalah nadzir yang kurang profesional. ${ }^{33}$ Suyono dkk dalam penelitiannya di Pesantren Modern Darussalam Gontor mengemukakan beberapa problematika pengelolaan aset wakaf pesantren secara produktif antara lain disebabkan adanya dominasi konsep wakaf sy/fïiyyah, nazhir belum profesional dan kondisi ekonomi dalam negeri. ${ }^{34}$

Dalam konteks pesantren, problematika yang muncul dapat berupa antara lain: Pertama, kedudukan wakaf pesantren yang mayoritas belum sepenuhnya menjadi institusi publik. Hal ini disebabkan karena ambiguitas pesantren sebagai institusi wakaf publik yang independen di satu sisi dan sebagai institusi yang di bawah otoritas kyai di sisi lain. ${ }^{35}$ Kenyataannya, otoritas kyai lebih dominan daripada kekuatan independensi publik dalam pesantren, mengingat kyai merupakan simbol sumber kekuasaan dan otoritas mutlak dalam pesantren sehingga ia sering kali dianggap sebagai orang yang memiliki self confident baik secara keilmuan, kekuasaan maupun manajemen pesantren. ${ }^{36}$ Kenyataan demikian pada gilirannya berdampak pada kekurangpedulian masyarakat untuk melihat pesantren sebagai institusi publik karena tidak ada mekanisme untuk mempertanyakan akuntabilitas institusi menyangkut lantaran institusi tersebut belum sepenuhnya menjadi akuntabilitas publik. ${ }^{37}$

Idealnya, wakaf sebagai institusi filantropi publik harus diposisikan sebagai milik publik sehingga bisa dikelola dan dipertanggungjawabkan kepada masyarakat dimana kyai beserta keluarganya juga berhak terlibat. Wakaf pesantren yang seperti ini dapat ditemukan di Pesantren Modern Darussalam Gontor dan Pesantren Tebuireng, keduanya melembagakan pesantren sebagai institusi wakaf publik di bawah manajemen yang independen sehingga terjadi perubahan kedudukan wakaf pesantren yang semula merupakan milik kyai sehingga otoritas kyai dan keluarganya lebih dominan berubah menjadi institusi milik publik. Pada tanggal 12 Oktober 1958, Pesantren Modern Darussalam Gontor yang ketika itu di bawah tiga orang

33 Uswatun Hasanah, Wakaf Produktif untuk Kesejahteraan dalam Perspektif Hukum Islam di Indonesia, Pidato Pengukuhan Guru Besar Hukum Islam UI tahun 2009, tidak dipublikasikan, hal. 18.

34 Yusuf Suyono dkk, Wakaf Produktif..., hal. 42-48.

35 Tuti A. Najib dan Ridwan Al-Makassary, Wakaf... hal.78.

36 Zamakhsyari Dhofier, Tradisi Pesantren:Studi tentang Pandangan Hidup Kyai. Cet. VI (Jakarta: LP3ES, 1994), hal. 56.

37 Tuti A. Najib dan Ridwan Al-Makassary, Wakaf.., hal. 78. 
kyai atau yang dikenal dengan trimurti menyerahkan pesantren tersebut kepada 15 orang wakil IKPM (Ikatan Keluarga Pondok Modern) yang selanjutnya disebut Badan Wakaf. Begitu juga Pesantren Tebuireng yang berdiri sejak akhir abad 19 M, pesantren ini telah melembagakan institusi wakafnya sebagai milik publik dengan pendirian Yayasan Hasyim Asyari sejak tahun 1947.

Problem kedua adalah bias status aset yang terjadi pada hasil pengembangan aset wakaf apakah ia berstatus sebagai wakaf secara otomatis ataukah sebagai milik pribadi kyai. Problem ini muncul manakala posisi wakaf masih dalam bentuk institusi yang disebutkan pada problem pertama sehingga progres produktifitas aset wakaf sulit terukur. Pondok pesantren Asshiddiqiyyah Kedoya Jakarta, misalnya, secara keseluruhan luasnya adalah mendekati 15 hektar. Tanah wakaf asalnya adalah $2.600 \mathrm{~m}^{2}$, selebihnya adalah hasil beli sendiri dari pengasuhnya. Kampus Karawang berluas 11,5 ha dengan tanah wakaf asalnya $5000 \mathrm{~m}^{2}, 10$ hektar berbentuk sawah yang diolah dan hasilnya digunakan untuk sebagian biaya operasional pesantren, selebihnya tanah seluas 11 hektar dibeli sendiri oleh pengasuh, begitupula aset yang ada di Kampus Batu Ceper Tangerang terdiri atas tanah wakaf seluas $6000 \mathrm{~m}^{2} \mathrm{dan}$ kampus terdiri atas tanah hasil sendiri dari pengasuh. ${ }^{38}$ Bias semacam ini, menurut Zamakhsyari Dhofier, terdapat dua pandangan yaitu pertama adalah harta tersebut milik kiai, dan kedua adalah berkedudukan sebagai benda wakaf sehingga tidak mudah menyimpulkan apakah semua institusi keagamaan tersebut dapat diidentifikasikan sebagai aset wakaf. ${ }^{39}$

Bias status aset wakaf di atas dapat juga terjadi pada strategi penggalangan dan pengembangan aset wakaf pesantren yang kadang masuk sebagai aset non wakaf karena berupa sadaqah atau hibah sehingga pengelolaannya tercampur dengan aset yang berstatus wakaf. Hal ini dapat ditemukan di Pesantren Modern Darussalam Gontor. Pengelolaan aset yang demikian sebagai konsekuensi penerapan sistem manajemen keuangan satu atap dengan alasan untuk memudahkan pengawasan dan keamanan, namun pada gilirannya menimbulkan kesulitan bagi pengukuran dan evaluasi tingkat kesuksesan aset murni wakaf itu sendiri. ${ }^{40}$

Problem yang ketiga adalah problem subyek hukum wakaf khususnya nazhir. Berdalih pada adagium "the man behind the gun", maka problem yang ketiga ini

38 Muhammad Fuad, Membangun...., hal. 74-75, 95.

39 Ibid, hal. 77.

40 Irfan Abu Bakar dalam Chaider S Bamualim dan Irfan Abubakar (ed), Revitalisasi..., hal. 240-241, 246-247. 
dapat dikatakan sebagai problem utama dalam pengelolaan wakaf secara produktif khususnya di dunia pesantren. Profesionalisme nadzir merupakan tuntutan yang tidak bisa ditawar dalam melaksanakan amanah pengelolaan harta wakaf secara produktif. ${ }^{41}$ Namun dalam kenyataannya, nazhir profesional khususnya di dunia pesantren boleh dikata relatif minim. Sekualitas Pondok Modern Darussalam Gontor saja masih terkategorikan semi profesional lantaran pengelolaannya masih menggabungkan pola tradisional dan profesional. ${ }^{42}$

Sumber utama dari problem subyek hukum wakaf khususnya nazhir adalah persoalan pemahaman (mainside). Mayoritas subyek hukum wakaf masih terpola pada pemikiran wakaf sebagai sesuatu hal yang abadi nan statis sehingga pada gilirannya benda yang diwakafkan cenderung pada benda yang tidak bergerak seperti tanah dan bangunan. Oleh karena itu pula wakaf kemudian tidak bisa diubah pada bentuk dan status yang lain khususnya ketika tidak dapat dimanfaatkan lagi bahkan aset tersebut sengaja dibiarkan punah ditelan masa sehingga kamus penukaran benda wakaf (istibd/l) atau penyegaran aset tidak pernah dikenal dalam pemikiran mereka. Pemahaman yang demikian menyebabkan aset wakaf menjadi statis dan nyaris komsumtif terkhusus ketika dalam kondisi yang unutilized. Di samping itu, praktik yang terjadi selama ini adalah nazhir dipilih secara asal-asalan sehingga rasa responsibilitasnya dalam pengembangan aset wakaf sangat minim dan tidak dapat diandalkan dan aset wakaf yang sebetulnya potensial menjadi tidak dioptimalkan produktifitasnnya bahkan cenderung konsumtif dimana wakaf yang sebetulnya diharapkan memberikan manfaat karena produktifitasnnya yang langgeng berubah menjadi wakaf yang menguras manfaat karena memerlukan biaya perawatan atas aset wakaf tersebut.

\section{E. Penutup}

Uraian dalam tulisan di atas mendeskripsikan tentang esensi wakaf sebagai salah satu institusi filantropi Islam yang harus dikelola secara produktif berbasis pada kemanfaatan aset yang langgeng. Di Indonesia, pesantren sebagai bagian dari institusi wakaf yang potensial sudah seharusnya merespon paradigma pengelolaan wakaf secara produktif tersebut, mengingat kenyataan selama ini pesantren relatif

41 Asmuni, Wakaf: Seri Tuntunan Praktis Ibadah. (Yogyakarta: Pustaka Insan Madani, 2007), hal. 70.

42 Yusuf Suyono dkk, Wakaf Produktif..., hal. 154. 
terkelola secara konsumtif. Tentu proses respon ini menimbulkan berbagai problematika yang antara lain adalah kepemilikan pesantren yang belum dipahami atau bahkan belum murni menjadi milik publik sehingga masyarakat tidak totalitas dalam membantu mengembangkan institusi sosial keagamaan berwajah pesantren tersebut, hal demikian menimbulkan problem selanjutnya yakni bias status aset wakaf antara sebagai milik wakaf atau milik pemegang pesantren dalam hal pengembangan aset wakaf, di samping campur aduk antara aset yang berstatus wakaf dan non wakaf dalam proses penggalangan dana dan pengembangan aset wakaf. Problem utama dalam hal ini adalah subyek hukum wakaf khususnya nazhir yang relatif belum memenuhi kompetensi sebagai nazhir profesional.

\section{DAFTAR PUSTAKA}

Abubakar, Irfan. 2005. "Pelembagaan Wakaf di Pesantren Tebuireng Jombang: Sebuah Upaya Merespon Kebutuan akan Perubahan” dalam Chaider S Bamualim dan Irfan Abubakar (ed). Revitalisasi Filantropi Islam, Jakarta: PBB UIN Jakarta.

- 2005. "Pengelolaan Wakaf di Pondok Modern Gontor Ponorogo: Menjaga Kemandirian Civil Society" dalam Chaider S Bamualim dan Irfan Abubakar (ed). Revitalisasi Filantropi Islam. cet I, Jakarta: PBB UIN Jakarta.

al-Bâqî, Ibrâhim Mahmûd 'Abd. 2006. Dawr al-Waqf fî Tanmiyat al-Mujtama' alMadanî. Kuwait: al-Amânah al-'Âmmah li al-Awqâf.

al-Bukhârî, Abî 'Abdillâh Muhammad bin 'Ismâ'îl. tt. Matn al-Bukhârî bi Hâasyiat al-Sanadî. Juz III. Beirut: Dâr al-Fikr.

al-Nawawî. tt. Shahih $\underline{h}$ Muslim bi Syarh al-Imâm al-Nawawî. Jilid VI, Beirut: Dâr alFikr.

Asmuni. 2007. Wakaf: Seri Tuntunan Praktis Ibadah, Yogyakarta: Pustaka Insan Madani.

as-Suyûthî, Jalâl al-Dîn. 1930. Sunan al-Nasâî bi Syarh Jalâl al-Dîn al-Suyûthî. Beirut: Dâr al-Fikr.

Azra, Azyumardi. 1997. "Pesantren: Kontinuitas dan Perubahan" dalam Nurchlis Madjid. Bilik-bilik Pesantren: Sebuah Potret Perjalanan, Jakarta: Paramadina. az-Zarqâ, Mu’ậfâ Ahmad. tt. Ahkâm al-Auqâf, t.tp: Dâr 'Ammâr. 
Dhofier, Zamakhsyari. 1994. Tradisi Pesantren:Studi tentang Pandangan Hidup Kyai. Cet. VI, Jakarta: LP3ES.

Dirjen Bimas Islam dan Penyelenggaraan Haji. 2003. Pedoman Pengelolaan dan Pengembangan Wakaf, Jakarta: Dirjen BIPH.

Fuad, Muhammad. 2008. Membangun Raksasan Tidur, Problematika Pengelolaan dan Pendayagunaan Wakaf di Indonesia, Piramedia: Depok.

Hasanah,Uswatun. 2009. Wakaf Produktif untuk Kesejahteraan dalam Perspektif Hukum Islam di Indonesia, Pidato Pengukuhan Guru Besar Hukum Islam UI, tidak dipublikasikan.

Huda, Miftahul. 2009. Fundrising Wakaf dan Kemandirian Pesantren: Strategi Nazhir Wakaf Pesantren dalam Menggalang Sumber Daya Wakaf, Makalah The $9^{\text {th }}$ Annual Conference on Islamic Studies (ACIS) di Solo, tidak dipublikasikan.

Ibn Hisyâm, Abî Muhammad 'Abd al-Malik. 2007. As-Sîrah al-Nabawiyyah, Beirut: Dâr al-Kutub al-'Ilmiyyah.

Jamal, Ah̆mad Muhammad 'Abd al-Ażim. 2007. Daur Nižâm al-Waqf al-Islâmî fî at-Tanmiyyah al-Iqti ầdiyyah al-Mu'ẩirah, Kairo: Dâr as-Salâm.

Mubarok, Jaih. 2008. Wakaf Produktif, Bandung: Simbiosa Rekatama Media.

Najib, Tuti A dan Ridwan al-Makassary. 2006. Wakaf, Tuhan dan Agenda Kemanusiaan, Jakarta: CSRC UIN Jakarta.

Qahaf, Mundzir. 2006. Al-Waqf al-Islâmî, Tathawwuruhu, Idârâtuhu, Tanmiyatuhu, Damaskus: Dâr al-Fikr.

Suyono,Yusuf. dkk. 2007. Wakaf Produktif di Indonesia: Studi atas Pengelolaan Aset Wakaf Pondok Modern Gontor Ponorogo,Semarang: IAIN Walisongo.

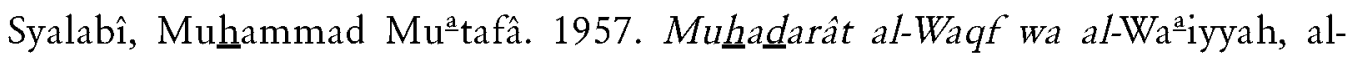
Iskandariyyah: Mapba'ah Dâr at-Ta’lîf.

Undang-Undang Nomor 41 Tahun 2004 tentang Wakaf.

Usman, Rahmadi 2009. Hukum Perwakafan di Indonesia, Jakarta: Sinar Grafika. Wahid, Abdurrahman. "Pesantren sebagai Subkultur" dalam M. Dawam Rahardjo (ed). 1974. Pesantren dan Pembaharuan, Jakarta: LP3ES. 
Wakaf Produktif dan Problematikanya........ 289

Zahrah, Muhammad Abû. 2004. Muḩadlarât fi al-Waqf, Kairo: Dı r al-Fikr al-'Araby. Zarkasyi, Abdullah Syukri. 2005. Manajemen Pesantren: Pengalaman Pondok Modern Gontor, Ponorogo: Trimurti Press. 